\title{
Stereoselective synthesis of perillaldehyde-based chiral $\beta$-amino acid derivatives through conjugate addition of lithium amides
}

\author{
Zsolt Szakonyi ${ }^{1}$, Reijo Sillanpää ${ }^{2}$ and Ferenc Fülöp ${ }^{* 1,3, \S}$
}

\author{
Full Research Paper \\ Address: \\ ${ }^{1}$ Institute of Pharmaceutical Chemistry, University of Szeged, H-6720 \\ Szeged, Eötvös utca 6, Hungary, ${ }^{2}$ Department of Chemistry, \\ University of Jyväskylä, POB 35, 40351 Jyväskylä, Finland and \\ ${ }^{3}$ Stereochemistry Research Group of the Hungarian Academy of \\ Sciences, H-6720 Szeged, Eötvös u. 6, Hungary \\ Email: \\ Ferenc Fülöp* - fulop@pharm.u-szeged.hu \\ * Corresponding author \\ § Tel.: +36-62-545564; Fax: +36-62-545705 \\ Keywords: \\ asymmetric synthesis; $\beta$-amino acid; chiral; Michael addition; \\ monoterpene \\ Beilstein J. Org. Chem. 2014, 10, 2738-2742. \\ doi:10.3762/bjoc. 10.289 \\ Received: 08 September 2014 \\ Accepted: 14 November 2014 \\ Published: 21 November 2014 \\ Associate Editor: S. Bräse \\ (C) 2014 Szakonyi et al; licensee Beilstein-Institut. \\ License and terms: see end of document.
}

\begin{abstract}
The Michael addition of dibenzylamine to (+)-tert-butyl perillate (3) and to (+)-tert-butyl phellandrate (6), derived from (S)-(-)perillaldehyde (1), resulted in diastereomeric $\beta$-amino esters 7A-D in a moderately stereospecific reaction in a ratio of 76:17:6:1. After separation of the diastereoisomers, the major product, cis isomer 7A, was quantitatively isomerized to the minor component, trans-amino ester 7D. All four isomers were transformed to the corresponding $\beta$-amino acids $\mathbf{1 0 A}-\mathbf{D}$, which are promising building blocks for the synthesis of $\beta$-peptides and 1,3-heterocycles in three steps. The steric effects of the isopropyl group at position 4 and of the $\alpha$-methyl substituent of $(R)-N$-benzyl- $N$ - $\alpha$-methylbenzylamine on the reactivity were also studied and, upon application of a chiral amine, excellent stereoselectivity of the conjugate addition was observed. Amino ester $\mathbf{1 1}$ was obtained as a single product and transformed to the corresponding amino acids 10A and 10D in good yields on the gram scale.
\end{abstract}

\section{Introduction}

In the past decade, cyclic $\beta$-amino acids proved to be versatile building blocks both in pharmacological developments and asymmetric syntheses [1-8]. Alicyclic and bicyclic chiral $\beta$-amino acids have played a key role in the synthesis of $\beta$-peptide-type foldamers, where through the selection of an appropriate alicyclic or bicyclic ring system, the backbone stereochemistry, stereochemical patterning or additional func- tional groups, well-defined $\beta$-helical (e.g., $\beta$-H12, $\beta$-H14, $\beta$-H16 or $\beta$-H18) or $\beta$-sheet structures can be prepared [9-13]. While it is primarily the backbone stereochemistry that determines the secondary structure of foldamers, the introduction of welldesigned hydrophilic or hydrophobic substituents on the alicyclic ring of $\beta$-amino acids can modify the fine structure of $\beta$-peptides. 
There are several powerful synthetic methods through which alicyclic or bicyclic $\beta$-amino acid enantiomers can be obtained. These include the selective reduction of $\beta$-enamino ester enantiomers [14], enzyme-catalyzed kinetic resolution [15], and a variety of asymmetric syntheses, for example, the enantioselective syntheses of $\beta$-lactams followed by ring opening [16,17], or the enantioselective desymmetrization of achiral anhydrides followed by Curtius degradation [18-20].

The highly stereoselective Michael addition of lithium amidetype nucleophiles to $\alpha, \beta$-unsaturated esters also proved to be a very efficient and useful method for the preparation of alicyclic $\beta$-amino acids in homochiral form [21,22]. Generally, in these transformations, the source of chirality is served by chiral lithium amides, and there are only few examples where chiral $\alpha, \beta$-unsaturated esters are applied [23-27].

Easily obtainable chiral monoterpenes, such as $(+)-3$-carene as well as all the enantiomers of pulegone, $\alpha$-pinene and verbenone, have frequently been used as starting materials for the preparation of chiral reagents and as unique synthons in asymmetric syntheses of $\beta$-amino acids and 1,3-amino alcohols, which in turn can be applied as chiral additives, catalysts or building blocks [17,28-34]. From this aspect, chiral, monoterpene-based $\alpha, \beta$-unsaturated esters might be excellent starting materials, in which the natural monoterpene skeleton may serve as the chiral origin for the stereoselective construction of the $\beta$-amino acid moiety.

Our present aim was the synthesis of new, limonene-based chiral $\beta$-amino acid derivatives derived from commercially available (-)-perillaldehyde (1). These 4-isopropyl-substituted analogues of ACHC (2-aminocyclohexanecarboxylic acid) might serve as promising building blocks for the synthesis of chiral 1,3-heterocycles and foldamers [7,11,23,35].

\section{Results and Discussion}

The key intermediate Michael acceptor, tert-butyl perillate (3), was prepared by a combination of literature protocols, starting from commercially available (-)-(4S)-perillaldehyde (1) in a two-step reaction. First, oxidation of 1 led to perillic acid (2) [36], which was subsequently converted to the tert-butyl ester (3) [37]. In order to study the steric effect of the more bulky isopropyl group on the Michael addition, (4S)-tert-butyl phellandrate (6) was prepared via (4S)-phellandral (4) and (4S)-phellandric acid (5) (Scheme 1) [38-40].

The asymmetric Michael addition was accomplished by the reaction of in situ generated achiral lithium dibenzylamide with compound 3 following a published protocol [23], to exploit the effect of the isopropenyl group on the cyclohexene ring. An

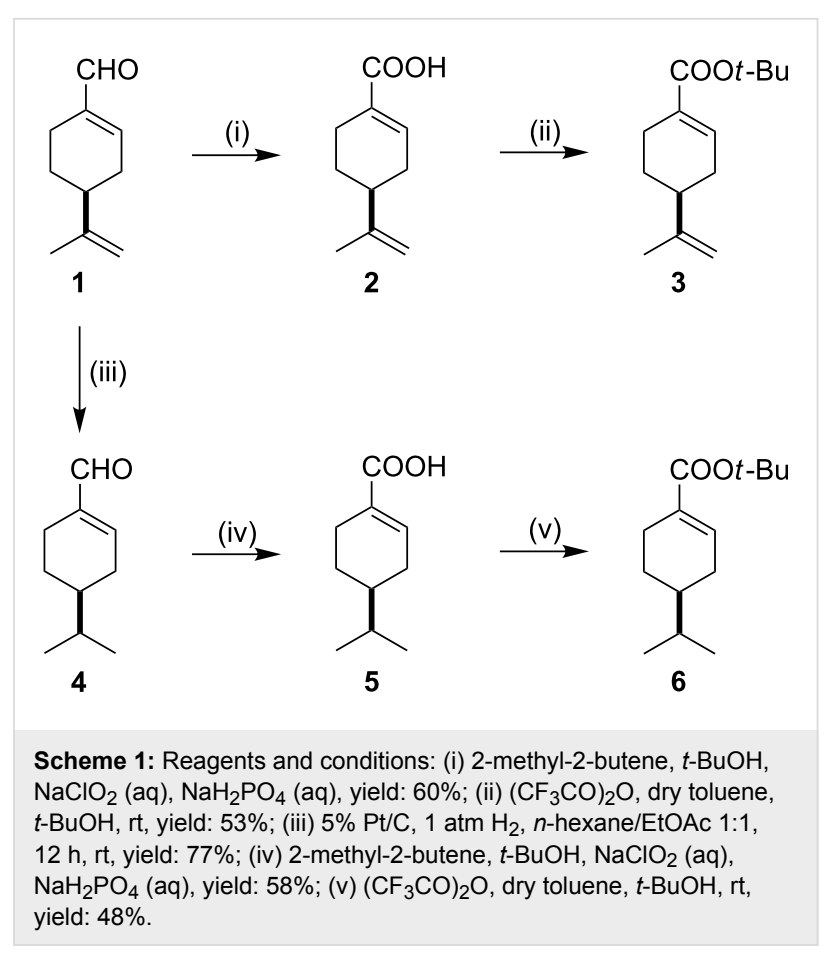

NMR study of the crude product demonstrated the good stereoselectivity of the addition. The ${ }^{1} \mathrm{H}$ NMR measurements of the crude product indicated that all four possible diastereosomers are formed in a ratio 7A:7B:7C:7D = 76:17:6:1 (Scheme 2). The diastereoisomers 7A-D could be successfully separated through a two-step chromatographic process, and their relative configurations were determined by 2D NMR techniques. Remarkable nOe correlations were observed between $\mathrm{C} 2-\mathrm{H}$ and C9-Me (10A and 10D), between $\mathrm{C} 1-\mathrm{H}$ and C8-H (10A), and a weak effect was found between $\mathrm{C} 1-\mathrm{H}$ and $\mathrm{C} 8-\mathrm{H}$ (10B) (see Figure 1 for numbering).

Amino esters 7A-D were transformed to the appropriate amino acids $10 \mathrm{~A}-\mathbf{D}$ in three steps. The selective reduction of the isopropenyl double bond over a $\mathrm{Pt} / \mathrm{C}$ catalyst resulted in $\mathbf{8 A}-\mathbf{D}$. The subsequent removal of the benzyl groups by hydrogenolysis over palladium on carbon $(\mathrm{Pd} / \mathrm{C})$ in a $1: 1$ mixture of $n$-hexane/EtOAc for $24 \mathrm{~h}$ gave primary amino esters 9A-D in excellent yields. The final hydrolysis of the ester groups under acidic conditions successfully led to amino acids 10A-D.

In addition to the NOESY experiments, the relative configuration of 10D was determined by means of X-ray crystallography (Figure 1).

The Michael addition was also carried out on 6, the 7,8-dihydro analogue of tert-butyl perillate (3), however the saturation of the isopropenyl function at position 4 proved to have no effect on the stereoselectivity of the reaction (Scheme 3 ). 


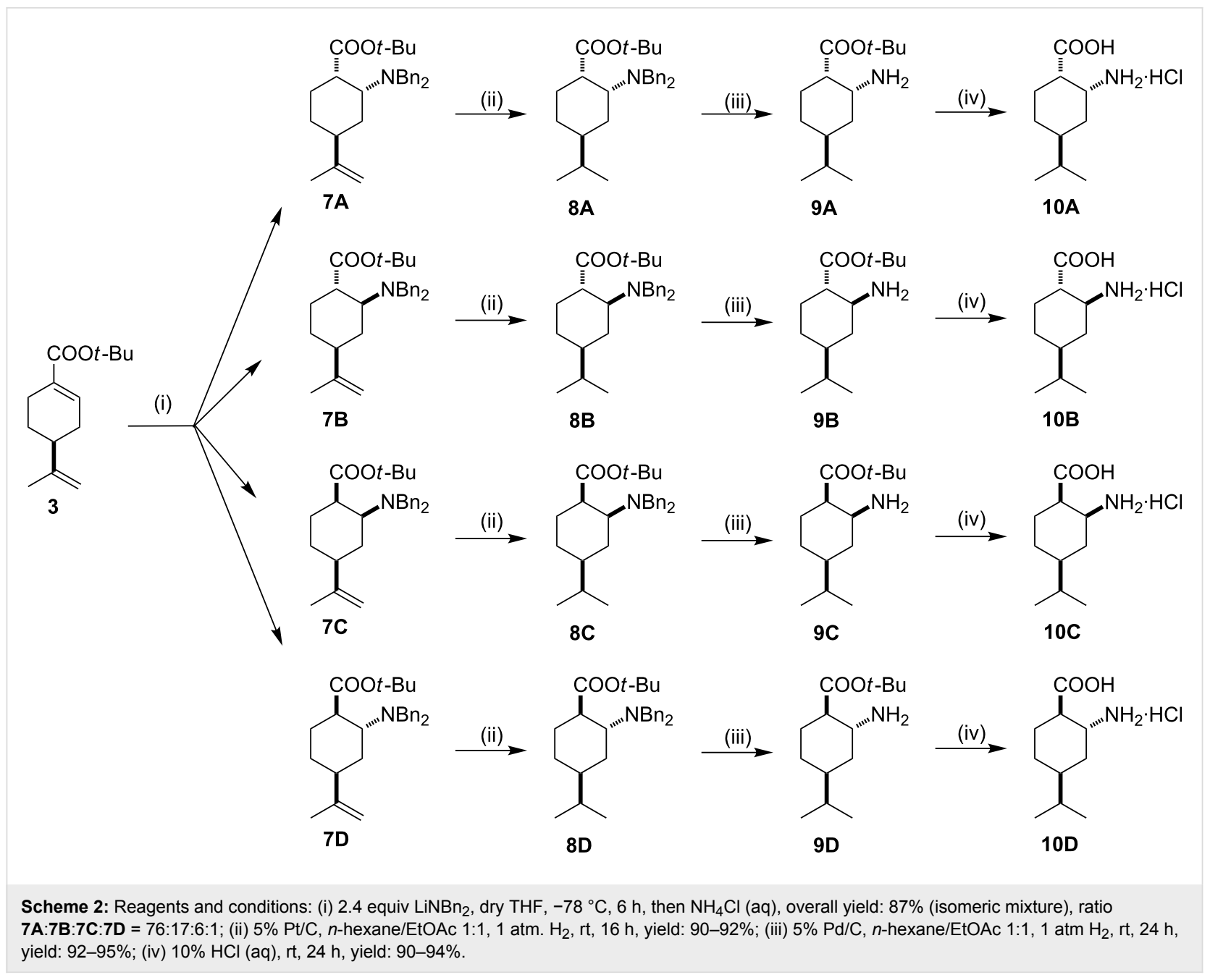

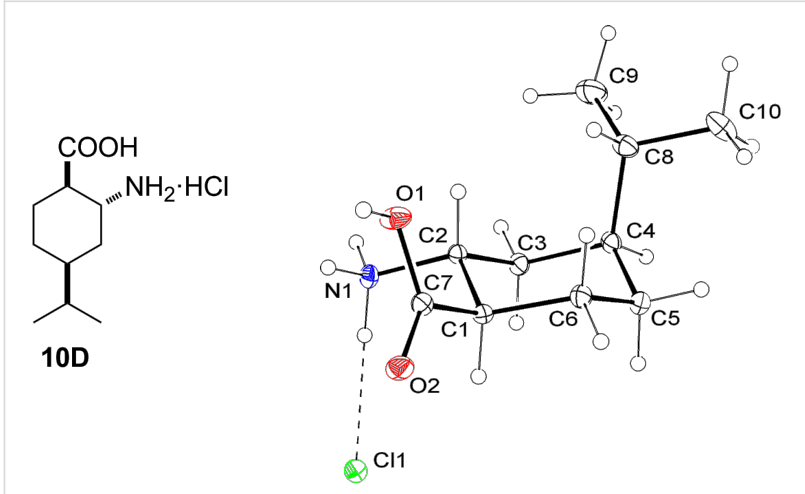

Figure 1: Structure of 10D and an ORTEP plot of its configuration.

When $N$-benzyl- $N$ - $\alpha$-methylbenzylamine was applied as a chiral nucleophile in the conjugate addition, the steric effect of the $\alpha$-methyl substituent could be investigated. The addition was proven highly stereoselective (de $>99 \%$ ), based on the ${ }^{1} \mathrm{H}$ NMR data of the crude product and cis-amino ester $\mathbf{1 1}$ as a single product was obtained in gram-scale quantities and high

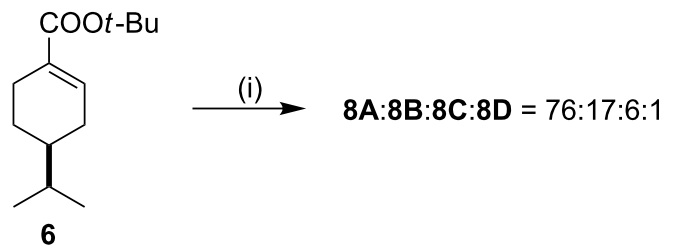

Scheme 3: Reagents and conditions: (i) 2.4 equiv $\mathrm{LiNBn}_{2}$, dry THF, $-78{ }^{\circ} \mathrm{C}, 6 \mathrm{~h}$, then $\mathrm{NH}_{4} \mathrm{Cl}(\mathrm{aq})$, overall yield: $85 \%$ (isomeric mixture).

yield (Scheme 4). In addition to the NOESY examinations, the relative stereochemistry of $\mathbf{1 1}$ was also proven through its conversion to $\mathbf{9 A}$ in two steps.

Applying ( $S$ )- $N$-benzyl- $N$ - $\alpha$-methylbenzylamide as a chiral lithium amide, only formation of the mixture of diastereoisomers with very low yield (ca. 10\%) was observed.

Under alkaline conditions, cis-amino esters $\mathbf{7 A}$ and $\mathbf{1 1}$ underwent isomerization at the carboxylic function, resulting in 


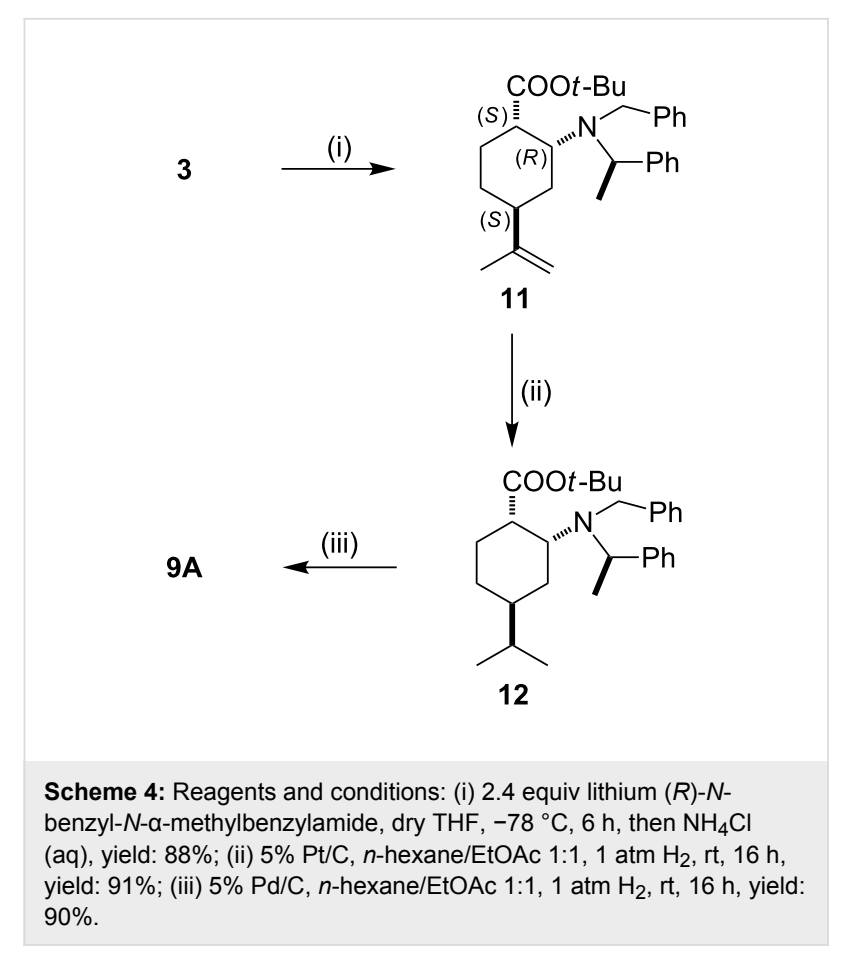

trans-amino esters 7D and $\mathbf{1 3}$ in excellent yields (Scheme 5). The relative stereochemistry of $\mathbf{1 3}$ was proven through its conversion to 9D in two steps. This rapid and quantitative isomerization allows the gram-scale synthesis of the minor component amino acid 10D (see Scheme 2).<smiles>[R12]N[C@@H]1C[C@H](C(=C)C)CC[C@H]1C(=O)OC</smiles>

7A, 11

\section{(i)}
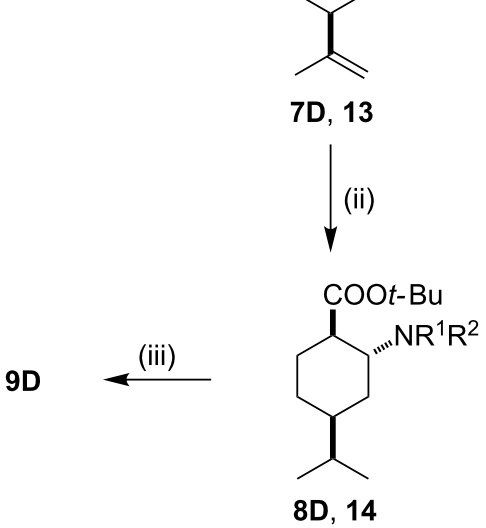

7A, 7D, 8D: $R^{1}=R^{2}=B n$

11, 13, 14: $\mathrm{R}^{1}=\mathrm{Bn}, \mathrm{R}^{2}=(R)-\mathrm{MeCHPh}$

Scheme 5: Reagents and conditions: (i) 0.2 equiv KOt-Bu/t-BuOH $40{ }^{\circ} \mathrm{C}, 24 \mathrm{~h}$, yield: $93 \%$ (7D), $91 \%$ (13); (ii) $5 \% \mathrm{Pt} / \mathrm{C}, n$-hexane/EtOAc 1:1, $1 \mathrm{~atm} \mathrm{H}_{2}$, rt, $16 \mathrm{~h}$, yield: $90 \%$ (8D), $91 \%$ (14); (iii) $5 \% \mathrm{Pd} / \mathrm{C}$, $n$-hexane/EtOAc 1:1, $1 \mathrm{~atm} \mathrm{H}_{2}$, rt, $16 \mathrm{~h}$, yield: $92 \%$.

\section{Conclusion}

In conclusion, the highly stereoselective Michael addition of lithium dibenzylamide and ( $R$ )- $N$-benzyl- $N$ - $\alpha$-methylbenzylamide to tert-butyl perillate (3) proved to be an efficient method for the preparation of limonene-based $\beta$-amino acids through the three-step transformation of the resulting $N, N$-dialkyl $\beta$-amino esters 7A-D and 11. The minor component, transamino acid 10D, was successfully prepared on gram-scale quantities through the facile isomerization of the cis-amino esters under alkaline conditions. It appears likely that the resulting new monomers 10A-D incorporated in a $\beta$-peptide sequence will be able to force the formation of unique $\beta$-helix or $\beta$-sheet structures, thereby affording a novel route to promising $\beta$-peptides.

\section{Supporting Information}

\section{Supporting Information File 1}

General information, experimental details, characterization data and copies of ${ }^{1} \mathrm{H}$ and ${ }^{13} \mathrm{C}$ NMR spectra. [http://www.beilstein-journals.org/bjoc/content/ supplementary/1860-5397-10-289-S1.pdf]

\section{Acknowledgements}

We are grateful to the Hungarian Research Foundation (OTKA NK81371 and K112442) for financial support.

\section{References}

1. Kuhl, A.; Hahn, M. G.; Dumić, M.; Mittendorf, J. Amino Acids 2005, 29, 89-100. doi:10.1007/s00726-005-0212-y

2. Juaristi, E.; Soloshonok, V. A., Eds. Enantioselective Synthesis of ß-Amino Acids, 2nd ed.; Wiley-VCH: New York, 2005. doi:10.1002/0471698482

3. Fülöp, F. Chem. Rev. 2001, 101, 2181-2204. doi:10.1021/cr000456z

4. Fülöp, F.; Martinek, T. A.; Tóth, G. K. Chem. Soc. Rev. 2006, 35, 323-334. doi:10.1039/b501173f

5. Trabocchi, A.; Scarpi, D.; Guarna, A. Amino Acids 2008, 34, 1-24. doi:10.1007/s00726-007-0588-y

6. Torres, E.; Acosta-Silva, C.; Rúa, F.; Álvarez-Larena, Á.; Parella, T.; Branchadell, V.; Ortuño, R. M. Tetrahedron 2009, 65, 5669-5675. doi:10.1016/j.tet.2009.05.039

7. Szakonyi, Z.; Fülöp, F. Amino Acids 2011, 41, 597-608. doi:10.1007/s00726-011-0891-5

8. Kiss, L.; Fülöp, F. Chem. Rev. 2014, 114, 1116-1169. doi:10.1021/cr300454h

9. Cheng, R. P.; Gellman, S. H.; DeGrado, W. F. Chem. Rev. 2001, 101, 3219-3232. doi:10.1021/cr000045i

10. Mándity, I. M.; Wéber, E.; Martinek, T. A.; Olajos, G.; Tóth, G. K.; Vass, E.; Fülöp, F. Angew. Chem., Int. Ed. 2009, 48, 2171-2175. doi:10.1002/anie.200805095

11. Hetényi, A.; Szakonyi, Z.; Mándity, I. M.; Szolnoki, É.; Tóth, G. K.; Martinek, T. A.; Fülöp, F. Chem. Commun. 2009, 177-179. doi:10.1039/b812114a 
12. Fernandes, C.; Faure, S.; Pereira, E.; Théry, V.; Declerck, V.; Guillot, R.; Aitken, D. J. Org. Lett. 2010, 12, 3606-3609. doi:10.1021/ol101267u

13. Martinek, T. A.; Fülöp, F. Chem. Soc. Rev. 2012, 41, 687-702. doi:10.1039/c1cs15097a

14. Cimarelli, C.; Palmieri, G. J. Org. Chem. 1996, 61, 5557-5563. doi:10.1021/jo960107y

15. Forró, F.; Fülöp, F. Mini-Rev. Org. Chem. 2004, 1, 93-102. doi: $10.2174 / 1570193043488908$

16. Alcaide, B.; Almendros, P.; Aragoncillo, C. Chem. Rev. 2007, 107, 4437-4492. doi:10.1021/cr0307300

17. Szakonyi, Z.; Martinek, T. A.; Sillanpää, R.; Fülöp, F. Tetrahedron: Asymmetry 2008, 19, 2296-2303. doi:10.1016/j.tetasy.2008.09.026

18. Bolm, C.; Schiffers, I.; Dinter, C. L.; Defrère, L.; Gerlach, A.; Raabe, G. Synthesis 2001, 1719-1730. doi:10.1055/s-2001-16745

19. Atodiresei, L.; Schiffers, I.; Bolm, C. Chem. Rev. 2007, 107, 5683-5712. doi:10.1021/cr068369f

20. Hameršak, Z.; Roje, M.; Avdagić, A.; Šunjic, V. Tetrahedron: Asymmetry 2007, 18, 635-644. doi:10.1016/j.tetasy.2007.02.019

21. Davies, S. G.; Smith, A. D.; Price, P. D. Tetrahedron: Asymmetry 2005, 16, 2833-2891. doi:10.1016/j.tetasy.2005.08.006

22. Davies, S. G.; Fletcher, A. M.; Roberts, P. M.; Thomson, J. E. Tetrahedron: Asymmetry 2012, 23, 1111-1153. doi:10.1016/j.tetasy.2012.08.009

23. Szakonyi, Z.; Balázs, Á.; Martinek, T. A.; Fülöp, F. Tetrahedron: Asymmetry 2010, 21, 2498-2504. doi:10.1016/j.tetasy.2010.09.009

24. Davies, S. G.; Durbin, M. J.; Goddard, E. C.; Kelly, P. M.; Kurosawa, W.; Lee, J. A.; Nicholson, R. L.; Price, P. D.; Roberts, P. M.; Russell, A. J.; Scott, P. M.; Smith, A. D. Org. Biomol. Chem. 2009, 7, 761-776. doi:10.1039/b818298a

25. Magano, J.; Bowles, D.; Conway, B.; Nanninga, T. N.; Winkle, D. D. Tetrahedron Lett. 2009, 50, 6325-6328. doi:10.1016/j.tetlet.2009.08.119

26. Davies, S. G.; Ichihara, O.; Roberts, P. M.; Thomson, J. E. Tetrahedron 2011, 67, 216-227. doi:10.1016/j.tet.2010.10.067

27. Cailleau, T.; Cooke, J. W. B.; Davies, S. G.; Ling, K. B.; Naylor, A.; Nicholson, R. L.; Price, P. D.; Roberts, P. M.; Russell, A. J.; Smith, A. D.; Thomson, J. E. Org. Biomol. Chem. 2007, 5, 3922-3931. doi:10.1039/b712937h

28. Ager, D., Ed. Handbook of Chiral Chemicals; Taylor \& Francis: Boca Raton, 2006.

29. Lait, S. M.; Rankic, D. A.; Keay, B. A. Chem. Rev. 2007, 107, 767-796. doi:10.1021/cr050065q

30. Szakonyi, Z.; Balázs, Á.; Martinek, T. A.; Fülöp, F. Tetrahedron: Asymmetry 2006, 17, 199-204. doi:10.1016/j.tetasy.2005.12.011

31. Makaev, F. Z.; Malkov, A. V. Tetrahedron: Asymmetry 2006, 62, 9-29. doi:10.1016/j.tet.2005.09.001

32. Singh, R.; Ding, P.; Holland, S.; Goff, D. Pinane-substituted pyrimidinediamine derivatives useful as Axl inhibitors. WO Pat. Appl. WO2008/045978 A1, April 17, 2008.

33. Makaev, F. Z.; Vlad, L. A.; Bets, L. P.; Malinovskii, S. T.; Gavrilov, K. N.; Gdanets, M. Chem. Nat. Compd. 2010, 46, 528-533. doi:10.1007/s10600-010-9669-3

34. Moglioni, A. G.; García-Expósito, E.; Aguado, G. P.; Parella, T.; Branchadell, V.; Moltrasio, G. Y.; Ortuño, R. M. J. Org. Chem. 2000, 65, 3934-3940. doi:10.1021/jo991773c
35. Szolnoki, É.; Hetényi, A.; Martinek, T. A.; Szakonyi, Z.; Fülöp, F. Org. Biomol. Chem. 2012, 10, 255-259. doi:10.1039/c1ob06627g

36. Kitahara, T.; Horiguchi, A.; Mori, K. Tetrahedron 1988, 44, 4713-4720. doi:10.1016/S0040-4020(01)86174-3

37. Krishnamurti, R.; Kuivila, H. G. J. Org. Chem. 1986, 51, 4947-4953. doi:10.1021/jo00375a036

38. Cooke, R. G.; Macbeth, A. K.; Swanson, T. B. J. Chem. Soc. 1940 , 808-810. doi:10.1039/jr9400000808

39. Suga, T.; Sugimoto, M.; Fujita, K.; Matsuura, T. Bull. Chem. Soc. Jpn. 1966, 39, 2546-2547. doi:10.1246/bcsj.39.2546

40. Mori, K. Tetrahedron: Asymmetry 2006, 17, 2133-2142. doi:10.1016/j.tetasy.2006.07.030

\section{License and Terms}

This is an Open Access article under the terms of the Creative Commons Attribution License

(http://creativecommons.org/licenses/by/2.0), which permits unrestricted use, distribution, and reproduction in any medium, provided the original work is properly cited.

The license is subject to the Beilstein Journal of Organic Chemistry terms and conditions: (http://www.beilstein-journals.org/bjoc)

The definitive version of this article is the electronic one which can be found at: doi:10.3762/bjoc. 10.289 